\title{
PERUBAHAN PASAL 7 AYAT (1) UNDANG-UNDANG PERNIKAHAN NO. 1 TAHUN 1974 TERKAIT PENINGKATAN BATASAN USIA PERNIKAHAN DALAM TINJAUAN USHUL FIQH
}

\author{
${ }^{1}$ Galuh Retno Setyo Wardani, ${ }^{2}$ Muh. Khusni Tamrin, ${ }^{3}$ M. Midrorun Ni'am, \\ dan ${ }^{4}$ Noer Azizah \\ 1,2,3,4UIN Maulana Malik Ibrahim Malang \\ ${ }^{1}$ galuhretnosetya@gmail.com,2muh.khusni.t19@gmail.com, \\ 3midrorunniam88@gmail.com,dan ${ }^{4 a z i z a h a q e n j e 97 @ g m a i l . c o m ~}$
}

\begin{abstract}
The pros and cons about marital age problems in the revision of article 7 paragraph 1 of Law no. 1 of 1974 is still an important topic discussion, although it has been a constitutional court decision. Therefore, in this study, the authors collect arguments to support the revision of this law and using ushul fiqh as a method of analysis, so it can be widely accepted by all groups. The research describes arguments and rules that strengthen the revision of the law to provide benefits in society and describes components of discussion such as the background to the decision to increase the minimum age of marriage. This study argues that the revision of the law is correct and there is absolutely no deviation from religious provisions in Islamic law.
\end{abstract}

Keywords : Islamic Law, Law Number 1 of 1974, Age Marriage

\section{Abstrak}

Meskipun telah resmi diberlakukan menurut hasil keputusan Mahkamah Konstitusi, namun pro kontra terkait dengan revisi pasal 7 ayat (1) undangundang No. 1 tahun 1974 masih menjadi topik yang begitu hangat diperbincangkan. Kenyataan bahwa upaya para penentu kebijakan dalam hal menciptakan ketentua-ketentuan demi menghilangkan datangnya kemudaratan adalah perkara yang cukup rumit dan tidak serta merta diterima oleh semua kalangan. Oleh karenanya dalam penelitian ini, penulis mencoba untuk menghimpun argumen pendukung agar supaya revisi undang-undang ini dapat diterima dengan bijak oleh semua golongan. Dalam penelitian ini, penulis kemudian berusaha melakukan klarifikasi dengan revisi undangundang sebagai objek dan menempatkan ushul fiqh sebagai pisau analisis. Termaktub dalam penelitian ini beberapa dalil-dalil hingga kaidah-kaidah yang kesemuanya menjadi pendukung dan penguat lahirnya revisi undangundang sebagai upaya untuk memperoleh tujuan haqiqi yakni kemaslahatan umat serta usaha untuk menghilangkan kemudaratan. Problematika usia pernikahan yang menjadi inti bahasan dalam pasal 7 ayat (1) Undang-ndang no. 1 tahun 1974 menjadi pembahsan yang menurut penulis sangat urgent untuk dikupas tuntas menggunakan perspektif hokum islam. Dalam hal ini penulis menspesifikkan dalam tinjauan ushul fiqh. Dalam penelitian ini juga 
dipaparkan semua komponen bahasan terkait denga revisi undang-undang mulai dari latar belakang adanya revisi sampai kepada diputuskannya peningkatan usia minimal pernikahan melalui Mahkamah Konstitusi. Kemudian penulis memaparkan kaitan eratnya dengan ilmu ushul fiqh dengan menawarkan dalil dan kaidah pendukung, maka ditarik sebuah kesimpulan mendasar bahwa revisi undang-undang tersebut adalah benar dan sama sekali tidak terdapat penyimpangan dari ketentuan agama dalam hal ini hukum islam.

Kata Kunci: Hukum Islam, Undang-undang 1974, Usia Pernikahan

\section{PENDAHULUAN}

Beberapa bulan terakhir, pembahasan mengenai revisi pasal 7 ayat (1) Undang-undang No. 1 tahun 1974 terkait batas minimal usia pernikahan cukup ramai diperbincangkan. Wacana untuk meningkatkan batas usia pernikahan tersebut sebenarnya sudah cukup lama dicanangkan oleh pemerintah, langkah awal untuk melakukan revisi sendiri terhitung sejak desember 2018 lalu (kompas.com). Setelah melalui beberapa prosedur dan mekanisme yang berlaku, akhirnya ketukan palu atas perubahan tersebut dilaksanakan oleh MK tertanggal 16 September 2019 (liputan6.com). Sebagaimana revisi atau pengadaan undang-undang dalam bidang lain, revisi terkait pasal 7 ayat (1) Undang-undang No. 1 tahun 1974 juga tidak luput dari problem semacam itu. Judicial review pertama yang diajukan pada tahun 2015 terkait pasal tersebut ditolak oleh MK. Saat itu permohonan uji materi yang diajukan adalah peningkatan usia minimal pernikahan bagi perempuan adalah 18 tahun dari 16. Akan tetapi pada bulan Juni 2015 Mahkamah Konstitusi memutuskan untuk menolak permohonan tersebut dengan alasan open legal policy.

Tidak menyerah di sana, judicial review kedua atas pasal tersebut kembali diajukan pada tanggal 20 April 2017 dengan menambahkan materi yang diujikan yang kemudian akhirnya diperoses dengan berbagai upaya agar dapat dirampungkan sebelum pergantian anggota DPR. Sebelumnya, dinyatakan bahwa revisi terkait pasal tersebut baru dapat disahkan dalam kurun waktu tiga tahun, namun atas desakan dari beberapa pihak, akhirnya revisi tersebut disahkan pada 16 September 2019 lalu (voaindonesia.com).

Mengenai peristiwa tersebut, tentunya sebagai konstitusi yang berlaku di Indonesia dengan mayoritas penduduk yang beragama Islam, sebuah perundang-undangan haruslah sesuai prinsip-prinsip ajaran Islam. Tak lepas dari tuntutan tersebut juga berlaku pada UU No. 1 tahun 1974 yang pada asasnya memang merupakan turunan dari syariat Islam itu sendiri. Dari sana, dirasa perlu untuk menilik hasil revisi pada pasal 7 ayat (1) yang telah ditetapkan oleh pemerintah akan keselarasannya dengan ajaran Islam yang ideal melalui kacamata ushul fiqh. 
Penelitian yang digunakan adalah menggunakan pendekatan yuridis normatif yakni mengkaji hukum yang dikonsepkan sebagai norma atau kaidah yang berlaku dalam masyarakat dan menjadi acuan perilaku setiap orang. Norma hukum yang berlaku itu berupa hukum norma hukum positif tertulis bentuk lembaga, perundang-undangan, kodifikasi, undang-undang, peraturan pemerintahan dan seterusnya (Muhammad, 2004). Sumber datanya ialah dengan menggunakan data sekunder yang diperoleh dengan mempelajari peraturan perundang-undangan, buku-buku yang berkaitan dengan hukum, serta terkait informasi yang berhubungan dengan permasalahan tersebut. Pengumpulan data yang digunakan ialah dengan studi pustaka, yakni dilakukan dengan cara membaca, memahami, mencatat, memahami dan mengutip data-data yang diperoleh dari beberapa literatur yang berupa buku-buku ataupun peraturan hukum yang sesuai dengan dengan pembahasan yang terkait. Data yang telah di buat dianalisis menggunakan cara deskriptif kualitatif maksudnya ialah analisis data yang digunakan dengan menjabarkan secara rinci terhadap kenyataan satu objek dalam bentuk kalimat untuk memberikan gambaran yang lebih jelas terhadap permasalahan yang diajukan sehingga memudahkan untuk ditarik sebuah kesimpulan, sehinnga data tersebut menjadi suatu hasil pembahasan dan gambaran dengan menggunakan analisis data yang dikumpulkan bersifat deskriptif dalam bentuk kata-kata.

\section{PEMBAHASAN}

\section{Latar belakang perubahan pasal 7 ayat (1) UUP No. 1 tahun 1974}

Sebelum membahas lebih jauh mengenai perubahan pembatasan minimal usia pernikahan dalam Undang-Undang, adapun redaksi dari klausa dari pasal 7 ayat (1) Undang-Undang No. 1 tahun 1974 berbunyi sebagai berikut:

"Perkawinan hanya diizinkan jika pihak pria sudah mencapai umur 19 (sembilan belas) tahun dan pihak wanita sudah mencapai umur 16 (enam belas tahun) tahun."

Pasal tersebut ditetapkan mengingat prinsip dari Undang-Undang pernikahan adalah kematangan dan kemampuan dalam menjalani pernikahan, dan pada usia tersebut dianggap sebagai batas minimal seseorang untuk mengemban tanggung jawab berkeluarga. Setelah meniliki berbagai pendapat para ulama madzhab yang membahas terkait penetapan usia baligh dan taklif, kemudian melihat realitas sosial pada masa itu, diputuskanlah usia 19 tahun bagi laki-laki dan 16 tahun bagi perempuan dianggap cukup untuk menjalani sebuah pernikahan (Bastomi, 2016). 
Batas minimal yang telah ditetapkan pada pasal tersebut mungkin dianggap relevan pada masa itu, masa ditetapkannya UU No. 1 Tahun 1974. Akan tetapi seiring berjalannya waktu, perkembangan zaman bukanlah sesuatu yang dapat dihindari, seiring dengan perkembangan tersebut, banyak juga tuntutan pemenuhan kebutuhan yang mungkin di masa lalu bukan dianggap sebagai suatu problem jika tidak terpenuhi. Jika mengevaluasi pada masa ini, maka ada beberapa poin irelevansi yang menuntut adanya pembaharuan dalam redaksi pasal 7 undang-undang pernikahan. Seperti irelevansi mengenai hak mengenyam pendidikan lanjutan, dan irelevansi terhadap faktor kesehatan baik fisik maupun mental. Bagaimanapun, jika menengok fakta yang terjadi di lapangan, maka akan didapati kondisi masyarakat yang sudah banyak mengalami perubahan dari waktu ke waktu (Nugraha, dkk, 2019).

Pernikahan merupakan awal mula terbentuknya suatu keluarga yang akan menjadi komunitas atau ruang lingkup sosial paling kecil dari masyarakat. Kesejahteraan sebuah keluarga akan mempengaruhi kondisi lingkungan yang lebih luas. Semakin banyak keluarga yang dapat dikategorikan sebagai keluarga sejahtera, maka akan semakin baik pula kondisi masyarakat sosial pada lingkungan atau wilayah tersebut. Sejahtera dalam kasus ini tentulah bukan hanya dalam perkara meterial, melainkan juga menyangkut aspek-aspek non materi seperti kesehatan mental, pembentukan karakter, dan lain sebagainya. Untuk mewujudkan harapan itu, tentulah dibutuhkan individu yang dianggap matang dalam mengemban amanah berumah tangga agar keluarga yang dibentuk lebih bisa memenuhi tujuan dari pernikahan itu sendiri, yakni sakinah, mawaddah, wa rahmah. Sebaliknya, jika individu yang melangsungkan suatu pernikahan sendiri dianggap belum mampu, maka bisa saja terjadi hal-hal yang tidak diinginkan.

Seperti perceraian karena kurangnya kesadaran akan tanggung jawab sebagai seseorang yang telah berkeluarga, faktor kesehatan fisik seperti masalah selama kehamilan oleh ibu muda hingga kematian karena rentannya fisik seorang ibu muda untuk mengandung, atau kesehatan mental yang tertekan karena banyaknya masalah pelik yang dalam keluarga yang tentunya jauh berbeda ketika hidup sendiri atau menjadi lajang. Hilangnya kesempatan untuk mengenyam pendidikan yang lebih tinggi. Rawannya terjadi kekerasan dalam rumah tangga karena keterbatasan emosi, dan rawan terjadi penelantaran anggota keluarga (Mai, 2019).

Contoh kasus yang terjadi akibat pernikahan usia muda dari data yang diambil pada tahun 2014 dari DKI Jakarta yang notabennya merupakan kota metropolitan sekaligus ibu kota Republik Indonesia yang dianggap sebagai wilayah dengan pertumbuhan dan kemajuan yang lebih baik dari wilayah lain, pernikahan pemuda berusia dibawah 20 tahun di DKI Jakarta tercatat 
dalam kisaran 51,7\% dengan kasus aborsi karena tidak kesiapan untuk hamil tercatat sebanyak 6,71\%, usia pernikahan yang tidak mencapai 10 tahun tercatat 42, 5\%, tercatat 1 kematian dari 100 kelahiran bayi hidup, kasus kematian bayi, dan 93 kasus kematian ibu muda. Tidak berbeda dengan ibu kota, masih banyak wilayah-wilayah lain di Indonesia yang mengalami nasib serupa karena pernikahan usia muda (Djamilah dan Kartikawati, 2014).

Kasus-kasus seperti yang telah dijelaskan masih mengalami peningkatan dari tahun ke tahun. Dampak yang ditimbulkan sebenarnya tidak hanya selesai pada bertambahnya jumlah janda dan dua atau kesedihan keluarga yang ditinggalkan, melainkan akan timbul dampak jangka panjang yang akan terus berkesinambungan seperti mata rantai yang tidak akan putus (Djamilah dan Kartikawati, 2014), kecuali melalui tindakan nyata dari pemerintah.

Merespon gejolak sosial yang sedemikian rupa, para aktifis perlindungan anak dan wanita, baik dari oraganisasi sosial, KPAI, sampai para korban pernikahan anak-anak mulai mengajukan judicial review kepada MK yang dimulai pada tahun 2015, sayangnya permohonan tersebut ditolak dan baru dikabulkan setelah pengajuan ulang pada tahun 2017. Dengan melewati kerja keras dan perjalanan yang begitu panjang, akhirnya revisi pasal 7 ayat (1) Undang-Undang No. 1 Tahun 1974 terkait batas usia minimal pernikahan berhasil disahkan pada September 2019 lalu.

Sebenarnya tidak hanya Indonesia yang memberikan batasan terkait usia perkawinan kepada warga negaranya, beberapa negara lain juga mengatur hal tersebut tentunya dengan pertimbangan dan prosedur masingmasing. Berikut adalah contoh dari beberapa negara Islam yang menetapkan peraturan mengenai batasan usia minimal pernikahan kepada masyarakatnya (Iriani, 2015):

Tabel 1. Batasan Usia Minilai Pernikahan di Berbagai Negara

\begin{tabular}{|l|c|c|}
\hline Negara & Laki-laki/tahun & Perempuan/tahun \\
\hline Aljazair & 21 & 18 \\
\hline Bangladesh & 21 & 18 \\
\hline Tunisia & 19 & 17 \\
\hline Mesir & 18 & 16 \\
\hline Irak & 18 & 18 \\
\hline Libanon & 18 & 17 \\
\hline Libya & 18 & 16 \\
\hline Malaysia & 18 & 16 \\
\hline Maroko & 18 & 16 \\
\hline Pakistan & 18 & 16 \\
\hline Somalia & 18 & 18 \\
\hline Yaman Selatan & 18 & 16 \\
\hline Suriah & 18 & 17 \\
\hline
\end{tabular}




\begin{tabular}{|l|l|l|}
\hline Turki & 17 & 15 \\
\hline Jordania & 16 & 15 \\
\hline Yaman Utara & 15 & 15 \\
\hline
\end{tabular}

Sudah sewajarnya bagi sebuah negara untuk membuat aturan-aturan dan tata tertib yang harus dipatuhi demi menjaga stabilitas kehidupan warga negaranya, baik dalam ranah publik maupun privat. Sebab pada dasarnya keteraturan suatu urusan atau hukum dalam ranah publik juga tidak lepas dari peran keselarasan ruang lingkup kamar perdata atau hukum privat. Tidak terkecuali dalam hal ini yakni menyangkut mengenai masalah pernikahan dan segala aspek yang berhubungan dengan itu. Suatu hukum harus menjadi relevan untuk bisa diterapkan, dan dalam penerapannya, hukum selalu membutuhkan pembaharuan yang sesuai dengan konteks agar relasinya dengan masyarakat tetap bisa terjaga dan dipatuhi demi mewujudkan kepentingan dan kebaikan bersama.

\section{Tinjaun ushul fiqh terkait perubahan pasal 7 ayat (1) UUP No. 1 tahun 1974}

Hasil Pernikahan merupakan salah satu topik yang banyak dan sering diperbincangkan di kalangan ummat Islam. Teks-teks al-Qur'an juga tidak sedikit yang mengatur tentang hal ini baik dalam segi syarat, rukun, dan tata caranya. Walau demikian, sayangnya al-Qur'an tidak menyebutkan secra jelas mengenai batas minimal usia pernikahan bagi para pelaku yang hendak melangsungkan akad yang dikatakan sebagai mitsaqan ghalidzan tersebut. Terkait dengan fakta tersebut, sehingga terjadi banyak perbedaan di antara para ulama dalam menentukan batas usia minimal pernikahan karena dipengaruhi oleh realitas sosial yang berbeda-beda pada ruang lingkup masing-masing. Dalam literatur sekelas Fiqh 'ala Madzahib al-'Arba'ah yang merupakan kodifikasi fatwa-fatwa dari empat ulama' madzhab termasyhur dikalangan ummat Islam juga tidak menyebutkan secara konkrit mengenai batas usia minimal dalam melangsungkan pernikahan (Rohman, 2016). Memahami kenyataan tersebut, bisa jadi hal ini merupakan salah satu indikasi bahwa fleksibilitas mengenai batas minimal usia pernikahan ditentukan oleh kebutuhan dan berbagai faktor yang terjadi di masyarakat.

Akan tetapi, meski tidak ada penyebutan secara langsung batas usia minimal bagi para pelaku pernikahan, terdapat beberapa riwayat yang menerangkan tentang batas usia bagi seseorang yang dinyatakan baligh yang sekaligus menjadi rujuan para ulama madzhab dalam menentukan kapan seseorang akan dibebankan hukum taklif. Kebanyakan ulam mengatakan 
bahwa batasan usia baligh adalah 15 tahun untuk laki-laki berpatokan pada hadis riwayat Ibnu Umar sebagai berikut (Asrori, 2015):

$$
\text { ورضت عرضت عن النبي صلى الله عليه وسلم يوم أحد وأنا ابن أربع عشرة سنة فلم بجزبي بوم الحندق و أنا ابن عشرة سنة فأجازني }
$$

Artinya: "Aku mengajukan kepada Rasulullah SAW untuk megikuti perang Uhud, dan ketika itu aku adalah anak berusia 14 tahun, Rasulullah pun tidak mengizinkan. Lalu aku mengajukan diri untuk mengikuti perang Handaq, dan saat itu usiaku 15 tahun, kemudian Rasulullah mengizinkan.

Dan bagi ulama yang menyatakan bahwa usia baligh bagi perempuan adalah 9 tahun, melihat pada contoh pernikahan yang dilakukan oleh Nabi Muhammad SAW dengan Sayyidah 'Aisyah RA yang saat itu masih berusia 9 tahun sebagai mana hadis riwayat Imam Muslim berikut (Asrori, 2015):

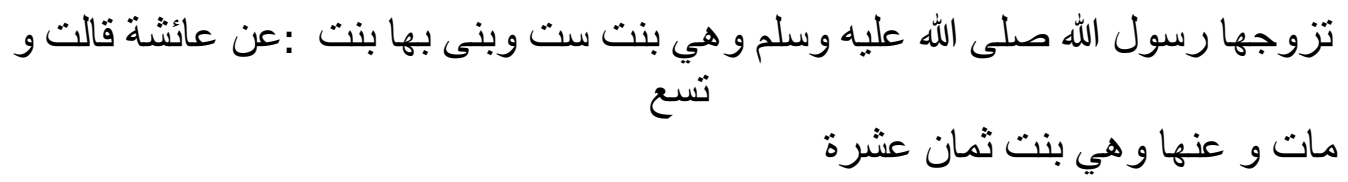

Artinya: "Rasulullah menikah dengan dia ('Aisyah) ketika berusia enam tahun, lalu memboyongnya ketik berusia sembilan tahun. Dan beliau wafat pada usia delapan belas tahun."

Jika menilik dari sudut pandang sosiologi pada masa itu, perempuan berusia sembilan tahun memang sudah dianggap dewasa dan cakap dalam beban tanggung jawab, baik secara fisik maupun psikis. Para gadis Madinah pada usia ini sudah bisa mengemban kewajiban mereka dan lebih mandiri. Dalam kasus ini dapat dilihat dari hadis Ibnu Sinan sebagai berikut (Ghazali, 2003):

$$
\text { إذا بلغة الجارية تسع سنين دفع إليها مالهاوجاز أمر ها وأقيمت الحدود التامة لها و عليها }
$$

Artinya: "Ketika anak perempuan sudah mencapai usia sembilan tahun, maka hartanya diserahkan kepadanya, urusannya dianggap boleh, dan dikenakan kepadanya maupun atasnya hukum pidana secara penuh."

Realitas yang ada pada masa itu tentunya sudah jauh berbeda pada masa ini, gambaran gadis berusia sembilan tahun yang dianggap sebagai minimal batas usia menikah pada masa itu nyatanya memang sudah dianggap dewasa, dan mumpuni dalam menangani berbagai urusannya sendiri, baik secara fisik maupun mental. Jika hendak membandingkan dengan melihat gadis sembilan tahun pada masa ini yang masih duduk di 
kelas empat SD dan sibuk bermain bersama teman-temannya, tentulah akan terjadi sebuah pertimbangan yang timpang. Sehingga pernyataan dan hukum yang diimplementasikan dan diaplikasikan kepada masyarakat pada kurun waktu itu, jelas tidak lagi relevan untuk diterapkan pada zaman ini, terlebih di Indonesia yang akhir-akhir ini mengalami krisis akibat pernikahan usia muda.

Hal ini selaras dengan nash al-Qur'an mengenai kelayakan bagi seseorang yang hendak melakukan pernikahan. Tertuang dalam surat al-Nur ayat 32 dengan redaksi sebagai berikut:

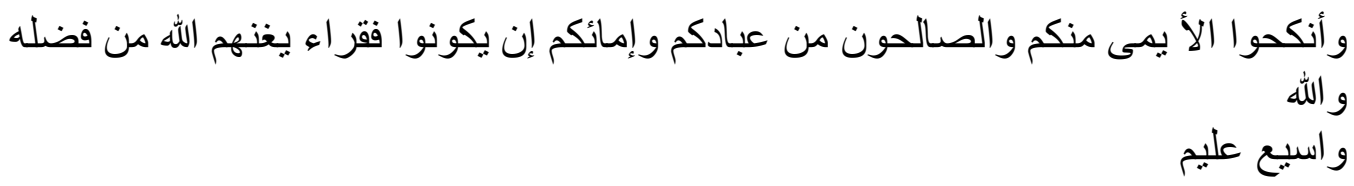

Artinya: "Dan kawinilah orang-orang yang sendiri di antara kamu, dan orang yang layak (berkahwin) dari hamba-hamba sahayamu yang lelaki dan permpuan. Jika mereka miskin, maka Allah akan memampukan mereka dengan karunia-Nya. Sesungguhnya Allah Maha Luas (pemberiannya) lagi Maha Mengetahui."

Dalam tafsir Ibnu Katsir, ayat ini melahirkan hukum tentang perintah bagi mereka yang telah mampu sebagaimana pendapat para ulama (alDamasyqi, 2004), sedang dalam Tafsir Maraghi sebagaimana yang dikutip oleh Mustofa, bahwa kata "sholihun" dalam ayat tersebut dimaksudkna bagi laki-laki dan perempuan yang berarti mampu memikul tanggung jawab atas kewajiban suami isteri, baik secara fisik maupun mental. Quraish Shihab menafsirkan bahwa yang dimaksud "sholihun" dalam ayat tersebut bukan dalam ruang lingkup taat beragama saj, namun lebih kepada kesiapan mental dan spiritual yang dibutuhkan dalam mejalani bahtera rumah tangga (Mustofa, 2009).

Apa yang tertuang dalam al-Qur'an terkait kelayakan dan sabda Nabi Muhammad pada masa itu memang selaras, karena kondisi masyarakat yang mempengaruhi usia dan ukuran kedewasaan juga sebagaimana yang tergambar dari riwayat-riwayat yang ada. Namun keumuman lafadz dalam al-Qur'an tentulah memiliki tafsiran yang tidak terbatas hanya pada makna yang sesuai dengan konteks saat itu, melainkan perlu dilakukan kontekstualisasi terhadap nash tersebut sehingga hukum yang diambil darinya tetap sholihun li kulli zaman wa makan sebagaimana prinsip hukum Islam dengan menyesuaikan kepada ruang lingkup sosial yang ada.

Jika mengaitkannya dengan revisi pasal 7 ayat (1) Undang Undang No. 1 tahun 1974 yang notabennya merupakan konstitusi remi yang berlaku di Indonesia mengenai minimal batas usia pernikahan yang telah ditingkatkan dari 16 tahun kepada 19 tahun bagi perempuan, tentunya hal itu tidak luput 
dari kacamata sosiologis-historis masyarakat Indonesia seperti yang telah disinggung pada pembahasan sebelumnya.

Setelah melalui perjalanan panjang, akhirnya perubahan tersebut berhasil disahkan secara resmi oleh MK, namun pengesahan tersebut disambut dengan berbagai macam reaksi dari khalayak, mulai dari yang pro hingga kontra. Beberapa pihak yang menentang dengan adanya dalih pernikahan adalah wujud dari ibadah, hingga dengan alasan akan membuka peluang bagi meningkatnya kasus nikah sirri. Jika menilik pada latar belakang perubahan Undang-undang itu sendiri, maka dapat dilihat dengan jelas bahwa di sini pemerintah berusaha untuk mengurangi atau bahkan mencegah segala mafsadat yang selama ini sudah banyak terjadi di masyarakat. Dari sudut pandang ushul fiqh, ada satu kaidah yang bisa menjadi acuan atas keputusan ini, yakni:

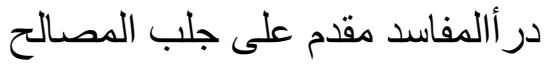

Artinya: "Menolak kerusakan lebih diutamakan daripada mengambil kemaslahatan."

Kaidah ini sendiri merupakan dalah satu dasar dari para ulama yang menggunakan metode saddu al-dzari'ah dalam menetapkan hukum, yakni dengan melakukan kehati-hatian jika menghadapi benturan antara maslahat dan mafsadat. Walau metode ini sendiri masih banyak dibahas oleh para ulama, namun tidak sedikit pula yang menggunakannya untuk menetapkan sebuah hokum (Syarifuddin, 2008). Selain kaidah tersebut, terdapat kaidah lain yang juga memiliki pemahaman senada dengan kaidah di atas, yakni:

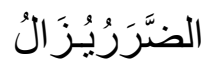

Artinya: "Kemudharatan harus dihilangkan".

Konsep yang dikandung dalam kaidah ini ialah, keharusan manusia untuk dijauhkan dari segala kemudharatan, baik dari diri manusia itu sendiri, pun juga demikian dengan orang lain yang ada di sekitar. Juga tidak dianjurkan kepada manusia untuk menebar kemudharatan kepada lingkungan sekitar (Washil dan Azzam, 2009). Inilah yang juga menurut penulis merupakan sebuah kaidah yang juga menjustifikasi adanya revisi undang-undang tentang batas minimal usia pernikahan. Mengapa demikian. Menurut penulis, ada visi yang dibawa oleh perubahan undang-undang ini. Salah satunya ialah visi menghilangkan atau minimal mengurangi kemudharatan. Betapa tidak, harmonis atau tidaknya sebuah bahtera rumah tangga sangat ditentukan oleh kematangan usia kedua mempelai.

Apabila dikaitkan dengan kemaslahatan dalam sebuah pernikahan yang merupakan suatu bentuk ibadah, namun kemafsadatan yang ditimbulkan oleh para pasangan muda yang melakukan pernikahan di bawah umur jelas 
menimbulkan dampak yang tidak kecil dan berkepanjangan. Dalam kasus ini pilihan untuk menolak kemafsadatan tersebut adalah pilihan terbaik, lagipula untuk mewujudkan kemaslahatan yang mungkin dicari dari sebuah pernikahan jika ada pasangan muda yang memang benar-benar ingin membina rumah tangga terlepas dari faktor apapun, masih ada solusi sebagaimana yang disebutkan pada ayat (2) pasal 7, yakni meminta izin dari pengadilan sebagaimana prosedur yang sebelumnya berlaku bagi mempelai di bawah umur 16 tahun. Setidaknya dengan kajian dari para ahli dan putusan hakim, kelayakan dalam pernikahan bisa dinilai secara subyektif dari proses tersebut.

Dalam Ushul al-Fiqh al-Islam dijelaskan bahwa ad-dzari'ah berarti wasilah untuk mencapai sesuatu. Dalam hal ini, ad-dzari'ah bisa dibagi dasar pemikirannya menjadi dua. Pertama, jika natijah dari dzari'ah tersebut fasid, maka hukumnya dilarang. Kedua, jika natijah dari dzari'ah tersebut merupakan mashlahat, maka diperintahkan (Zuhaili, 2017). Jika kerusakan yang tumbuh akibat pernikahan usia muda bisa dihindari dengan adanya peningkatan batas usia minimat pernikahan, maka perubahan tersebut bisa dipandang baik, atau bahkan diperintahkan.

Dalam menjawab kekhawatiran akan merajalelanya nikah sirri atau madharat yang lain, sebenarnya tidak sedikit kaidah yang memandang bahwa keyakinan tidak bisa digugurkan begitu saja dengan adanya keraguraguan maupun dzan. Sebuah asumsi memiliki beberapa tingkatan yang jika diperkirakan dalam persentasi maka bisa diperinci dalam tabel berikut (Tamrin, 2010):

Tabel 2. Asumsi dan Tingkatan Keyakinan

\begin{tabular}{|c|l|c|}
\hline Asumsi & \multicolumn{1}{|c|}{ Tingkatan } & Persentasi \\
\hline waham & $\begin{array}{l}\text { Kemungkinan yang lebih lemah dari dua } \\
\text { hal yang sedang diasumsikan. }\end{array}$ & $25 \%$ \\
\hline Syak & $\begin{array}{l}\text { Prasangka tanpa mengunggulkan salah } \\
\text { satu dari dua hal yang diasumsikan.. }\end{array}$ & $50 \%$ \\
\hline Dzanny & $\begin{array}{l}\text { Persepsi terhadap dua hal, dimana salah } \\
\text { satunya lebih kuat dari yang lain. }\end{array}$ & $75 \%$ \\
\hline Yaqin & $\begin{array}{l}\text { Kepercayaan yang disandarkan pada } \\
\text { sesuatu yang sudah pasti. }\end{array}$ & $100 \%$ \\
\hline
\end{tabular}

Kecurigaan dan kekhawatiran mengenai terjadinya hal-hal yang tidak diinginkan sebab keputusan untuk meningkatkan minimal usia pernikahan tidak cukup kuat untuk dijadikan sebagai hujjah sehingga mengabaikan fakta 
yang lahir sebab adanya bukti atas kerusakan yang banyak terjadi karena pernikahan dini. Hal ini selaras dengan kaidah yang meyatakan bahwa (Tamrin, 2010):

إن ما ثبت يقين لايرتفع إلابيقين

Artinya: "sesungguhnya sesuatu yang ditetapkan berdasarkan keyakinan tidak bisa dihilangkan kecuali dengan sesuatu yang diyakini pula."

Kaidah tersebut merupakan salah satu kaidah cabang dari salah satu kaidah pokok yang dirumuskan oleh para ulama dari prinsip metode istishab yang berjalan atas keraguan yang mengiringi kayakinan. Mengukuhkan pengalaman daripada suatu asumsi (Syarifuddin, 2008). Kaidah tersebut berbunyi:

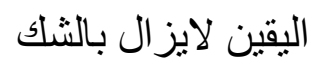

Artinya: "Apa yang ditetapkan atas suatu yang meyainkan, tidak dapat dihilangkan dengan sesuatu yang meragukan."

Setelah melalui berbagai macam penelitian dan pengamatan dalam waktu yang lama, efek dan akibat buruk atas bahayanya pernikahan pada usia muda telah banyak didapatkan dari seluruh daerah di Indonesia. Tentunya hal tersebut merupakan bukti konkrit yang tidak bisa dibantah. Mengambil keputusan dengan mengacu dan bertendensi pada hasil-hasil tersebut adalah sebuah keniscayaan. Tentunya setelah melalui kajian dan uji materi dari para ahli dalam bidangnya, keputusan untuk meningkatkan batas usia pernikahan dari 16 tahun ke 19 tahun tentulah sudah ditimbang kemaslahatannya bagi masyarakat Indonesia, terutama bagi mereka yang hendak melangsungkan pernikahan.

Sedangkan kekhawatiran atas dampak buruk yang mungkin muncul karena ketetapan tersebut sebenarnya bukan satu-satunya alasan mengapa hal itu terjadi. Seperti nikah sirri misalnya. Pernikahan sirri selama ini sudah menjadi masalah tersendiri bagi Indonesia yang dilatar belakangi oleh berbagai sebab. Mulai menghalalkan perselingkuhan, sikap acuh tak acuh akan sebuah aturan karena kurangnya kesadaran, menutupi kecelakaan, hingga alasan sebagai lahan bisnis. Kesimpulannya, baik dengan adanya peningkatan dari aturan minimal batas pernikahan maupun tidak adanya aturan tersebut, nikah sirri tetap menjadi sebuah tugas yang harus diselesaikan oleh masyarakat Indonesia.

Selain uraian di atas, salah satu asumsi yang dibangun oleh penulis adalah keyakianan bahwa diputuskannya revisi UU ini di Mahkamah Agung beberapa waktu lalu ialah semata-mata demi kemaslahatan dan juga upaya untuk menghindarkan dari kemudharatan. Olehnya itu, di sini akan dipaparkan secara deskriptif bagaimana revisi UU peningkatan batas 
minimal usia pernikahan diverifikasi lewat ketentua-ketentuan yang ada dalam maslahah mursalah.

Abdul Wahab Khalaf telah menjabarkan beberapa persyaratan yang harus dimiliki oleh sebuah perkara dalam fungsinya sebagai pengejawantahan dari maslahah mursalah (Efendi, 2005): (a) Perkara yang dianggap maslahah haruslah merupakan kemaslahatan yang hakiki. Yakni kemaslahatan yang betul-betul mendatangkan kemanfaatan atau penolakannya terhadap kemudaratan. (b) Perkara yang dianggap maslahah haruslah mengakomodir kepentingan umum dan bukan merupakan kepentingan pribadi. (c) Tidak menyimpang dari ketentuan al-Quran dan Sunnah.

Berangkat dari persyaratan dasar oleh Abdul Wahhab Khalaf, dapat ditarik sebuah hasil analisis bahwa benarlah kemudian justifikasi maslahah mursalah terhadap revisi uu tentang peningkatan usia pernikahan ini. Karena ketika dibenturkan dengan 3 persyaratan di atas, maka revisi uu tersebut telah lolos dalam proses verifikasi. Pertama, revisi uu ini merupakan benarbenar kemaslahatan yang haqiqi, karena dapat dikatakan bahwa jika revisi ini tidak diberlakukan, maka akan meningkatkan tingkat perceraian dan kehancuran rumah tangga yang disebabkan oleh kurang matangnya usia seseorang dalam berfikir dan menyelasaikan masalah. Kedua, revisi uu ini menjadi sebuah ketentuan umum dan akan diberlakukan umum sebagaimana uu itu berlaku. Ketiga, tidak terdapat dalil yang baik dari alQuran maupun sunnah yang kemudian membahas secara spesifik terkait dengan angka minimal usia pernikahan.

Pada akhirnya, meningkatkan batas minimal usia pernikahan merupakan solusi terbaik yang diambil pemerintah untuk mengatasi krisis hak asasi yang diterima oleh para pasangan muda, terutama pihak perempuan. Baik dalam sudut pandang sosiologis, psikologis, dan kesetaraan ha asasi, juga baik dalam tinjauan agama Islam melalui kacamata ushul fiqh. Dengan disahkannya perubahan ini, diharapkan angka dari kasus-kasus tidak diinginkan yang berhubungan dengan rumah tangga kiranya dapat berkurang.

\section{KESIMPULAN}

Dari penjelasan dalam bab sebelumnya, kurang lebih dapat ditarik dua kesimpulan. Pertama, alasan perubahan Pasal 7 Ayat (1) Undang-Undang Pernikahan No. 1 Tahun 1974 adalah karena faktor sosial. Banyaknya kasus yang disebabkan oleh pernikahan pada usia muda ketika pasangan dirasa belum sepenuhnya matang untuk mengemban tanggung jawab dalam berkeluarga seperti perceraian dini, aborsi, kematian ibu muda, kematian 
bayi, sampai kekerasan dalam rumah tangga, dan lain-lain terus mengalami peningkatan dari waktu ke waktu. Terjadinya perubahan dalam masyarakat, menuntut perubahan dalam hukum yang sesuai sehingga dapat diaplikasikan dengan baik dan benar. Peningkatan batas usia minimal pernikahan diambil sebagai solusi dari masalah tersebut.

Kedua, jika menilik revisi yang dilakuan pemerintah terkait Pasal 7 Ayat (1) UUP No. 01 Tahun 1974 melalui perspektif ushul fiqh, maka akan didapati bahwasannya nash baik al-Qur'an maupun Hadis secara tersirat sebenarnya membenarkan atas perubahan tersebut. Tidak adanya batasan baku dalam al-Qur'an mengenai batas usia miimal pernikahan menunjukkan fleksibilitas dari ayat tersebut, dalam hal ini merujuk pada ayat perintah untuk untuk menikah yang tertuang dalam surat al-Nur ayat 32. Dalam beberapa riwayat hadis yang menerangkan tentang batas kedewasaan sseseorang juga kerap menunjukkan adanya aspek sosiologis-historis yang menjadi rujukan dan gambaran kedewasaan bagi seseorang. Melalui pendekatan kaidah-kaidah ushul fiqh, dapat dipahami bahwasannya peningkatan batas minimal usia pernikahan tersebut memang merupakan solusi terbaik yang dapat diambil untuk menghadapi masalah perikahan dini yang terjadi di Indonesia.

\section{DAFTAR PUSTAKA}

Al-Damasyqi, Abi Fada' al-Hafidz Ibnu Katsir. (2004). Tafsir Ibnu Katsir. Beyrut: Al-Kutub Al-Ilmiyyah.

Asrori, Achmad. (2015). Batas Usia Perkawinan Menurut Fukaha dan Penerapannya Dalam Undang-Undang Perkawinan di Dunia Islam. Al'Adalah, 8(4).

Bastomi, Hasan. (2016). Penikahan Dini dan Dampaknya (Tinjauan Batas Umur Perkawinan Menurut Hukum Islam dan Hukum Perkawianan Indonesia. Yustisia. 2 (2).

Departemen Agama Republik Indonesia. (1998). Al-Qur'an dan Terjemahannya. Semarang: PT. Karya Toha Putra.

Djamilah dan Kartikawati, Reni. (2014). Dampak Perkawinan Anak di Indonesia. Jurnal Studi Pemuda, 3(1).

Efendi, Satria. (2005).Ushul Fiqih. Jakarta: Kencana.

Ghazali, Abdul Rahman, (2003). Fikih Munakahat. Jakarta: Kencana Pranata Media Group. 
Iriani, Dewi. (2015). Analisa Terhadap Batasan Usia Pernikahan Dalam UU No. 1 Tahun 1974. Justicia Islamca. 12(1).

Mai, Jessica Tiara. (2019). Tinjauan Yuridis Terhadap Perkawinan Anak Dibawah Umur Dilihat Dari Sudut Pandang Undang-Undang No. 1 Tahun 1974. Lex Crimen, 8(4).

Muhammad, Abdulkadir, (2004). Hukum dan Penelitian Hukum. Bandung: PT Citra Aditya Bakti.

Mustofa. (2009). Perbandingan Hukum Perkawinan di Dunia Islam. Bandung: Pustaka al-Fikris.

Nugraha, Xavier dkk. (2019). Rekonstruksi Batas Usia Minimal Perkawinan Sebagai Bentuk Perlindungan Hukum Terhadap Perempuan (Analisa Putusan MK No. 22/Puu-Xv/2017). Lex Scientia Law Review. 3(1).

Rohman, Holilur. (2016). Batas Usia deal Pernikahan Perspektif Maqashid Syari'ah. Journal of Islamic Studies and Humanities. 1(1).

Syarifuddin, Amir. (2008). Ushul Fiqh. Jilid 2. Jakarta: Kencana.

Tamrin, Dahlan. (2010). Kaidah-kaidah Hukum Islam. Malang: UIN Maliki Press.

Undang-undang No. 1 Tahun 1974 Pasal 7 ayat (1). (2017), Makassar: Grahamedia Press.

Washil, Nashr Farid Muhammad dan Azzam, Abdul Aziz Muhammad, (2009). Qawa'id Fiqhiyyah. Tk: Amzah.

Zuhaili, Wahbah. (2017). Ushul Fiqh al-Islam. Juz II. Damaskus: Dar el-Fikr. 